\title{
幼坚教育の基硴的研究
}

神奈川県松田中学校 東京大学:

○平阙あさ子

水 野 忠 文

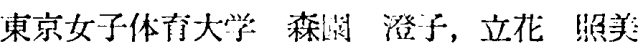

二公学舎大学森本富子

幼児期の基礎体育は，心理学や医学に頼りがちであっ たが，近頃は運動能力などのテストが积極的に行なわれ て，体育独自の傾向がでてきたようである，然し，奏際 の基礎体育としては未だ確たる体系は出来ていない，そ こで，幼児の基礎体育のあり方を究明するために実証的 研究を試みた。

\section{方 法}

東京都私立も又じ幼稚墽々児 4 才，5才142名を対象 とした。

1. Conformateur による立位側面，正面姿勢の 分 析. 口. 東京私立妙陮園協会健康研究班案に上る「幼児 渾動機能の発達尺度」及び坚童性研究考案による「幼 罗体力測定法」に従いテストした．本研究では以上の絬 果から 5 才児連動能力・機能の上位群 10 名, 下位群 10 名を選び分析を行なつた。

\section{秸 果}

(1) 侧面諸解度比沶いては，数字的变化がるられか
つた，(2) 両肩の均斉，乳頭の均斉，顔面の傾き，全身 左右の傾きに执いて两ると，運動能力の高い方の奻児以 均斉がれている。（3) 写具の主観的判定場によると， 渾動能力の离い幼児は」:半身がのびのびとしているよう に思われる. (4) 運動能力が售くてもゆがみの多い傾们

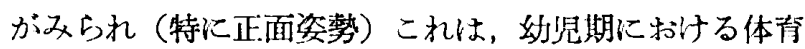
のめやすになると思われる．(i) 姿勢教育について考兄 てみると，骨の軟かいこの時期こそ，矯正体育的教育の 重要な段階であると思う。

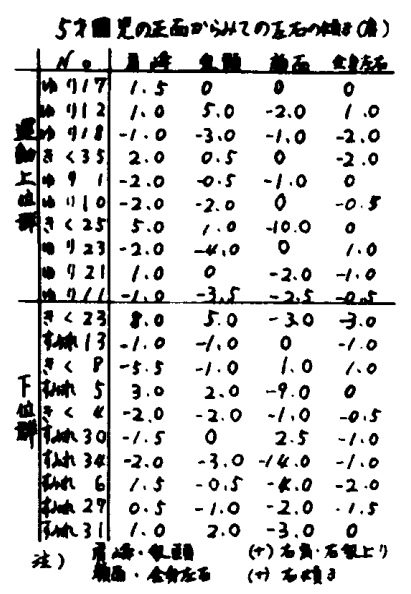

の相関係数は $0.62^{* *}$ でかなり高い相関があり，ボクシ ング $\mathrm{r}=0.66^{* *}$, レスリング $\mathrm{r}=0.81^{* *}$, 重量挙 $\mathrm{r}=0.9^{6}$ **となつていて，相関は極めて高いので，身長制が可 能である.

（2）身長に対する体重の回帰（big）と，体重に対 する身長の回帰 $\left(\mathbf{b}_{21}\right)$

$\mathrm{b}_{12}$ と $\mathrm{b}_{21}$ の[问帰直線をみると, 一般生徒は二つの[问 壎直線がかなり離れているが，ボクシングはやや近接 し，レスリングはかなり近接し，重量挙は極めて近接し ている.このことは，一般生徒に比して，身長 $1 \mathrm{~cm}$ 当 りの体重の割合が多く，反対に， $1 \mathrm{~kg}$ 当りの身長の割 合が少なくなつていることを意味しており，身長制の的 能性を強めている。

\section{(3) 体直区分と身長区分}

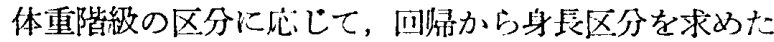
結果では，身長制に代えても57\%は階級が変らず，下の 階級になる者 $20 \%$ ，上の階級になる者 $23 \%$ で，この雨茯 はほぼ相殺されるため身長制の不合理は認められれない。

以上のことから，発充期にある高校生に対しては，理 行のルールに促われず，思い切つて身長制を採用するこ とが体青人としての道であると考劣る。

（泪） **は1\%の危険率で有意を示す。

$$
\begin{aligned}
& b_{12} \cdots \cdots \hat{Y}=\bar{y}+b(X-\bar{x}) \\
& b_{91} \cdots \cdots \hat{Y}=\tilde{x}+b(Y-\bar{y})
\end{aligned}
$$

高校 17 才男子 1,337 人の 全国調查です，身長と作重 